\title{
Palma y la Literatura de Francia: una aproximación
}

Por Oswaldo Holguín Callo 
Historiador. Doctor en Historia por la Pontificia Universidad Católica del Perú. Miembro de la Academia de la Historia y de la Academia Peruana de la Lengua. Ha realizado investigaciones históricas y bibliográficas en Perú, España, Estados Unidos y Chile. 


\section{Introducción}

Conocida es la estrecha relación de Palma con la literatura castellana; menos se sabe, sin embargo, de sus vínculos con la francesa, hacia la cual, después de aquella, dirigió su curiosidad e interés, recibiendo a cambio no poca influencia ${ }^{1}$. No solo su propia voluntad y la tendencia imperante en el medio limeño hicieron que Palma se inclinara hacia los escritores españoles y franceses, también estos se hallaban más a su alcance por obvias razones históricas y coyunturales. Los autores contemporáneos, románticos y de otras escuelas, eran los más accesibles, y la legión de sus admiradores devoraba sus producciones, pero los clásicos no estaban al margen y avisos como el siguiente solían reunirlos muy democráticamente:

\section{Amena lectura.}

Se acaban de recibir en la Imprenta de J. Masías, calle de la Pescadería núm. 127, las obras siguientes: Obras escogidas de Zorrilla, Espronceda, Bretón de los Herreros, Gil y Zárate, Quevedo, Harzembuch [sic], Mora, Molière, Béranger, Racine, \&a., \&a. [...] Un gran surtido de novelas de Dumas².

1 "Por ser tan numerosas las alusiones de Palma a obras francesas, se deduce que, de todos los idiomas modernos, excluyendo el español, conocía mejor la literatura francesa" (Winn, "Más sobre las fuentes y documentos de información de que se sirvió Ricardo Palma: sus lecturas en lenguas extranjeras”, p. 803).

2 Cf. El Heraldo de Lima, 11 mar. 1856, 500, p. 1, col. 2 (en adelante 1, 2). 
Por cierto, no solo la literatura gálica tuvo un papel destacado en la formación cultural de Palma, también Francia y sus súbditos, las amistades afrancesadas y, en general, lo francés,alcanzaron a lo largo de su vida, en diferentes momentos y circunstancias, un especial relieve. Ello ocurrió por ser Francia una de las principales potencias europeas, por ejercer un brillante papel en la cultura occidental y, entre otros factores, por participar, a través de sus diplomáticos, empresarios e inmigrantes, en diversas esferas de la vida peruana.

En el Perú del siglo XIX, sobre todo en los estratos medios y altos, era una norma social lograr un decoroso dominio de la lengua gala. Clases de francés constituían parte apreciada de la educación de los limeños de la incipiente burguesía y, ciertamente, de la aristocracia vieja y nueva, los cuales solían alcanzar los grados colegiales, la secundaria del presente, pero, menos que hoy, la universidad. Palma era todavía un niño cuando recibió clases de francés en el colegio de Clemente Noel, donde por octubre de 1845 fue examinado en analogía, lectura y traducción del Telémaco e historia romana, ocupando el octavo lugar en el curso completo; de allí pasó al de Antonio Orengo "teniendo nociones del idioma francés, las que, a insinuación de su padre [Pedro Palma], llevó adelante... con el objeto de perfeccionarse"; en efecto, "por mi afición a los idiomas y principalmente al francés, me decidí a continuar en su estudio y concluir las tres partes esenciales que me faltaban, es decir la sintaxis, prosodia y ortografía", materias en las que fue presentado como alumno destacado en los exámenes públicos ofrecidos a fines de $1846^{3}$.

3 Cf. Holguín Callo, Tiempos de infancia y bohemia. Ricardo Palma (1833-1860), pp. 112-13. 
Su conocimiento del francés le permitió leer no solo a numerosos autores clásicos, románticos, parnasianos, etc., sino a autores europeos no franceses vertidos a la lengua gala, v. gr. el viajero inglés Stevenson y los alemanes Samuel Pufendorf ${ }^{4}$ y, especialmente, el poeta Enrique Heine (1797-1856), de quien tradujo varias poesías 5 . Palma apreciaba la lengua francesa y le gustaba practicarla, prueba de lo cual son las muchas palabras y expresiones que empleó en sus obras debido a su fuerza expresiva, eufonía u otra motivación sociolingüística, como la nota de buen gusto que su uso traía aparejada ${ }^{6}$. Ello no le impidió rechazar con energía la presencia de galicismos, la "galiparla" modernista, postura que sin embargo no llevó a extremos ${ }^{7}$. Tampoco dejó de emplear términos del lenguaje coloquial con que se apellidaba a los súbditos franceses ${ }^{8}$.

Por otra parte, las élites peruanas solían recibir una fuerte dosis de historia francesa a través de la instrucción que recibían, y no pocas familias tenían a uno de sus miembros en Europa, lo que era decir París, bien por estudios o en viaje de placer. Palma conoció muchas páginas de la historia de Francia a raíz de la enseñanza colegial, de los numerosos dramas y novelas históricas que, respectivamente, presenció y leyó, de las atractivas publicaciones ilustradas que, procedentes de Francia

4 Cf. Palma, Tradiciones peruanas completas (en adelante TPC), pp. 1736 y 1737; y Winn, op. cit., p. 806.

5 Se valió de la traducción realizada por el francés Gérard de Nerval (Poesías completas, p. 151, nota).

6 "Соnnu!, que diría un francés" (TPC, p. 260); égratignure: arañazo (TPC, p. 1310); literatura mignone (TPC, p. 1515); causeur ("Recuerdos de España. 1892 a 1893", p. 154); "si noblesse oblige, reputation oblige aussi" (Epistolario, I, p. 333); "concurrencia de gente comme il faut" (Cartas inéditas, p. 57).

7 Véase sus Dos mil setecientas voces que hacen falta en el Diccionario. Papeletas lexicográficas, pp. viii, 248 (defiende "revancha”) y 249-50; asimismo, criticó la fórmula "mi esposo y yo" por "amaneradamente francesa”, etc. (TPC, p. 1516).

8 Gabacho (TPC, p. 1506, 1515-16; y Dos mil setecientas... cit., p. 130); y franchute (TPC, p. 974). 
y España, ofrecían un importante caudal de lectura histórica, etc. Señal de su familiaridad con el pasado y presente francés son las frecuentes menciones que en sus tradiciones hizo de Carlomagno, Enrique IV, Napoleón I, Napoleón III, Ney y Murat, Cambronne (citado por Hugo), Gambetta, Thiers, Sedan, San Bartolomé, etc. ${ }^{9}$.

\section{Palma y la literatura francesa}

Sin embargo, en el siglo XIX no hubo para las élites intelectuales peruanas aspecto más conocido de la cultura francesa que la literatura de sus autores románticos. Palma vivió en ese contexto y, por lo mismo, leyó con marcado interés a los poetas, autores teatrales y novelistas galos desde adolescente, aunque sus primeros contactos ocurrieron en la niñez ${ }^{10}$. En efecto, después de los españoles, fueron los escritores franceses los que más atención le merecieron y, por lo mismo, mayor influencia hubieron de ejercer sobre él ${ }^{11}$. Entre los poetas, Alphonse de Lamartine (1790-1869) ${ }^{12}$, Alfred de Musset (1810-1857) y Víctor Hugo $(1802-1885)^{13}$, según propio testimonio ${ }^{14}$, pero también Gérard de Nerval (1808-1855) ${ }^{15}$, Pierre-Jean de Béranger (1780-1857) ${ }^{16}$ y una misteriosa Mme. $B^{* * *}$ cuyos versos le sirvieran en 1848 para epigrafiar una loa a Gamarra rebosante

9 Véase TPC, índice onomástico.

10 Entre otros, se han ocupado del tema Riva-Agüero ("Elogio de don Ricardo Palma") y Winn ("Más sobre las fuentes..." cit.).

11 Cf. Holguín Callo, Tiempos de infancia y bohemia... cit., pp. 209-12. El estudio de esa influencia escapa a la índole de este ensayo histórico.

12 Cf. Núñez, "La efusión sentimental: Lamartine y Musset".

13 Cf. Núñez, "La conmoción romántica: Víctor Hugo"; y Silva-Santisteban, Víctor Hugo en el Perú, pp. 56-65.

14 Cf. "Recuerdos de España..." cit., p. 135.

15 Cf. "Consolación. Confidencias", p. 20.

16 Cf. El Correo[Peruano], 1897, apud El Comercio, Lima, 18 agosto, 1854, 45 13, 3, 5. 
de entusiasmo juvenil ${ }^{17}$. Entre todos, Hugo fue su preferido ${ }^{18}$, sobre todo en su primera juventud, seguramente por sus altos ideales y el mensaje social transmitido en sus obras, preferencia que lo llevó a traducir sus poesías"La conciencia", "Traducción" (después "La mujer caída"), "Confrontaciones", "Esperanza en Dios", "Nomen, numen, lumen", "Dios es amor", "Sedan", "Desdén", "Necedad de la guerra", "A mi hija", "Fragmento" y "El estanque"19. Algunas traducciones ya figuraron en Armonías. Libro de un desterrado (1865), poemario que no recoge versos de otros autores, señal clara de su particular admiración al creador de Los miserables.

Datan de 1860 sus versiones castellanas de dos poesías de Hugo que posiblemente ejecutó alentado por Ignacio Noboa. La primera, "La conciencia", capítulo del poema La Légende des siècles (La leyenda de los siglos), refiere el incesante huir de Caín y su familia perseguidos por la mirada de Dios, y los vanos esfuerzos de los hijos del fratricida para ayudarlo a burlar la sanción divina:
Airada tempestad se desataba, cuando, vestido de salvajes pieles, Caín con su familia caminaba huyendo a la justicia de Jehovah. La noche iba a caer. Lenta la marcha al pie de una montaña detuvieron y a aquel hombre fatídico dijeron sus tristes hijos: -Descansemos ya.

17 Cf. ibíd., 25 nov. 1848, 2824, 4, 2.

$18 \mathrm{Al}$ morir Hugo en 1887, en una velada literario-musical organizada por el Ateneo de Lima, el 3 de agosto de ese año, Palma leyó la poesía "Víctor Hugo", del ecuatoriano Nicolás Augusto González, dedicada "A mi maestro y amigo Ricardo Palma" (véase la bibliografía).

19 Palma, Poesías, pp. 329-40; y Poesías completas, pp. 143-50. Palma las tomó de diversas obras de Hugo: La leyenda de los siglos, Las contemplaciones, Las hojas de otoño, Los castigos, etc. Alguna vez citó Los castigos y El año terrible para justificar la poesía política que había escrito (Epistolario, I, p. 332). 
Duermen todos, excepto el fratricida que alzando sus miradas hacia el monte vio en el fondo del fúnebre horizonte Un ojo fijo en él. Se estremeció Caín y despertando a su familia del dormir reacio, cual siniestros fantasmas del espacio retornaron a huir. iSuerte cruel! ${ }^{20}$.

El trabajo, dedicado a Noboa, notable político e intelectual educado en Francia que conocía la tarea y que, por el mismo tiempo (1859-1860), publicó un extenso estudio de las últimas poesías de gran vate francés ${ }^{21}$, le deparó elogios y palabras de aliento -Palma ya no era un novato y el asunto lo había seducido por su misterio y suspenso-, como los del respetado Felipe Pardo y Aliaga, también traductor juvenil de Hugo, quien "quiso que le fuese presentado para felicitarme. Nada hay que halague tanto al soldado raso como alcanzar, en el campo de batalla, una distinción o enhorabuena del general", diría años más tarde con sincera emoción, añadiendo:

Aunque la parálisis tenía postrado todo su cuerpo, el cerebro del egrejio [sic] literato conservaba toda su lucidez. Nunca habría yo podido imaginarme que mi traducción, que es casi literal, realzara la grandeza del original francés, mérito que acaso no debo considerar como exclusivo de mi ingenio, sino que toca en mucho a la índole de la lengua. El monótono martilleo del alejandrino gálico, no alcanza a revestir la idea de la solemnidad que la prestan el endecasílabo y el

20 Véase la bibliografía y Armonías, pp. 77-80. La Légende des siècles, vasto poema en el que Hugo pasa revista a toda la historia de la humanidad, se publicó en tres series, la $1^{\mathrm{a}}$ en 1859 , de la cual tomó Palma el fragmento señalado apenas un año después.

21 Cf. Moreyra y Paz Soldán, "Pedro Ignacio Noboa y Benavides, economista, político, literato, diplomático”, p. 265; y Núñez, "Víctor Hugo en el Perú”, p. 21. 
eptasílabo castellano [sic]. Hoy mismo sigo creyendo, como don Felipe Pardo, que mi traducción de "La conciencia" es de lo mejor que, en verso, ha salido de mi pluma ${ }^{22}$.

Poco antes (feb. 1858), Palma había expresado conceptos muy honrosos sobre la obra escénica del "fundador de nuestro teatro..." 23 .

La segunda, "Traducción [de Víctor Hugo]”, después llamada "La mujer caída”, es una vigorosa defensa de la mujer pecadora y un canto a su valor. El poeta se conduele de la condición femenina débil y desamparada:

iiiNunca insultéis a la mujer caída!!!

¿Quién sabe con qué afán ha combatido?

¿Bajo qué peso su alma ha sucumbido?

¿Qué abismo se entreabrió bajo sus pies?

¡Ah! No es de la mujer... iNuestra es la culpa!

Tuya es la falta, isociedad menguada!

¿Quién no vio a la mujer, débil y aislada, luchar y reluchar con el dolor? 24

Quizá el tratamiento de un tema como el expresado obedeciera más que a una motivación literaria a una de carácter social o religioso, ya que por entonces Palma profesaba cierto radicalismo ultraliberal ${ }^{25}$.

22 Cf. "La bohemia de mi tiempo. 1848 a 1860. Confidencias", pp. 31-32. También el argentino Rafael Obligado admiraba esta traducción (Palma, Epistolario, II, p. 40, cit. por Winn, "Más sobre las fuentes..." cit., p. 805).

23 Cf. "Prólogo", en Segura,Teatro, p. iv.

24 Véase la bibliografía.

25 Sobre las traducciones de poesías de Hugo véase Holguín Callo, Tiempos de infancia y bohemia... cit., pp. 277-79. 
En cuanto a Lamartine, Palma fue uno de sus declarados admiradores peruanos así como un imitador de su estilo y motivos de inspiración-sobre todo en las numerosas "armonías" que escribió ${ }^{26}-$, pero más tarde, cuando en 1865 lo vio en París, su figura y su aspecto lo decepcionaron:

Cuando en mi primer viaje a Europa, cediendo a petulante empeño mío, mi amigo el poeta argentino Hilario Ascasubi me llevó, en París, a casa de Lamartine, a pesar de que estaba yo aún en plena mocedad, no experimenté emoción igual a la que ante Zorrilla sentía. En Lamartine, el hombre me desencantó a los cinco minutos. Me pareció un simple mortal, con levita negra y corbatín de cerda, uno de tantos que pasean el boulevard de la Magdalena. No correspondió a mi ideal, lo confieso ${ }^{27}$,

Sin embargo, de esa relación en la vejez se complacía recordando su visita al egregio francés, así como su casual encuentro callejero con Paul de Kock (1793-1871), notable novelista de la época ${ }^{28}$.

Palma también sintió devoción por Musset ${ }^{29}$.En su primer viaje a Europa (1864-1865), Palma disfrutó intensamente, en París,

26 A partir de 1853 empezó a emplear, al frente de ciertas poesías, la voz "armonías", seguramente tomada de Harmonies poétiques et religieuses (Armonías poéticas y religiosas), tercera recopilación poética de Lamartine (1830) que también influyó en las Armonías (1851) del argentino José Mármol, a quien Palma cantó en versos ese año (cf. Cejador y Frauca, Historia de la lengua y literatura castellana, VII, p. 348). Ya maduro, Palma publicó una breve versada titulada "A Gabriela (álbum). Pensamiento de Lamartine" (Filigranas, p. 21; y, ampliada como "Pensamiento de Lamartine", en Poesías completas, p. 283).

27 Recuerdos de España..." cit., p. 139. Tauzin Castellanos sostiene que las decepciones que Palma sufriera en París lo apartaron del romanticismo ("Los románticos peruanos y París”, inc. 'Ricardo Palma: el fin de la ilusión romántica’).

28 Riva-Agüero, “D. Ricardo Palma”, p. 14. Quizá se trató de su hijo, Henri de Kock (1819-1892), también novelista popular.

29 Citó sus versos al frente de su poesía necrológica “iiEnrique Alvarado!!” (1856) y mencionó su muerte en "Consolación. Confidencias" (véase la bibliografía y "Consolación. Confidencias”, p. 20, respec.). 
de la Opéra y la Comédie Française, faceta que hizo pública en la crónica que, bajo el título de "Una visita a la tumba de Alfredo de Musset", envió a su amigo Vicente G. Quesada, codirector con Miguel Navarro Viola de La Revista de Buenos Aires, prestigiosa publicación que la difundió a fines de $1864^{30}$. El escrito nos muestra a un Palma gratamente impresionado por una pieza teatral de Musset -"On ne badine pas avec l'amour" ("No se juguetea con el amor")-, estado de ánimo que lo lleva a confesar algo de su credo liberal y romántico:

iAtrás los que os soñáis poetas y que pensáis que marcháis hacia adelante, cuando no alcanzáis con versos artísticamente elaborados a conmover al pueblo porque solo le habláis de vuestro yo y de vuestras miserias! Hablad al pueblo del pasado y del porvenir, evocad sus tradiciones y dadles vida, habladle de sus dolores y tristezas, habladle de libertad y de amor, habladle de sus glorias, como lo hizo Musset, y el pueblo os premiará con sus lágrimas, con sus aplausos. Viviréis por fin en el corazón del pueblo, la más pura y la más envidiable de todas las glorias. iSí! El poeta para merecer tal nombre ha de corresponder a las exijencias [sic] de su siglo y del pueblo al que ofrece sus inspirados $\operatorname{cantos}^{31}$.

El arte de Musset le produjo tan honda satisfacción que, en compañía del coronel y poeta argentino Hilario Ascasubi, visitó su tumba en el célebre Cementerio del Père Lachaise ${ }^{32}$. Versos rebosantes de emoción dieron remate al reverente gesto $^{33}$.

30 Véase la bibliografía. La crónica está datada en París, 8 oct. 1864.

31 "Una visita a la tumba de Alfredo de Musset", p. 484.

32 Ibíd., p. 487.

33 "En la tumba de Alfredo de Musset", en su Armonías, p. 192. Véase también Holguín Callo, "Palma, cónsul en el Pará", pp. 51-52. 
En cuanto a la literatura dramática, muchos fueron los dramas franceses que Palma leyó y vio representar, pero consideraba a Víctor Hugo (1802-1885), Delavigne(1793-1843) y Alejandro Dumas padre (1802-1870) asi miro sus mejores representantes ${ }^{34}$. La dramaturgia de Hugo era muy reconocida en Lima y su amigo y compañero el "bohemio" José Toribio Mansilla había hecho una "admirable traducción en verso" del drama "Marion Delorme" 35. El alto merecimiento que a Palma le motivaba la obra escénica de Hugo se trasluce en esta expresión de ponderación referida al exitoso estreno de su drama "Rodil": "iQué noche aquella! Víctor Hugo me la habría envidiado" 36 .Dando cuenta de su familiaridad con la obra huguiana, en 1853 anotó que estaba de moda el catolicismo de Balmes y, por la noche, Triboulet, Hernani, Ruy Blas, Lucrecia Borgia, vale decir prosaicos personajes y dramas del célebre escritor ${ }^{37}$.

Dumas padre fue otro de sus autores preferidos en los dilatados campos de la dramaturgia gala. En La bohemia ... citó sus dramas "Anthony" y "Teresa", así como la comedia "Las señoritas [colegialas] de Saint-Cyr"38. Dumas, cuyas obras eran a menudo representadas en Lima, le inspiró primero admiración y más tarde rechazo. Así, cuando en 1851 se entregó con ingenua confianza a la creación de los dramas "La hermana del verdugo", "La muerte o la libertad" y "Rodil", debió de escribir: "[Dumas] retrata con más perfección que muchos los caracteres de la sociedad..."; sin embargo, dos años después

34 Palma, TPC, p. 1310.

35 "Prólogo" en Segura, Teatro, p. v. Mansilla, que también escribió el drama "Nuestra Señora de París", adaptación de la homónima novela de Hugo estrenada en Lima en jul. 1849 (cf. Holguín Callo, Tiempos de infancia y bohemia... cit., p. 292), fue un "bohemio" con experiencia europea que debió de contribuir a la afición literaria francófona de Palma.

36 "La bohemia..." cit., p. 24.

37 Cf. Lida, I, pp. 2 y 3.

38 "La bohemia..." cit., p. 44. Winn cree que también conoció el drama "Margarita de Borgoña", de Dumas y Gaillardet ("Más sobre las fuentes...” cit., p. 804). 
hizo suya la crítica de Luis Mariano de Larra (1830-1901) a su drama "Anthony": "Anthony, hijo de una fantasía calenturienta, no es el corazón del hombre tal como la Divinidad lo formó; tal como quiso que fuera"; en 1855 se refirió a sus "dramones" y, otra vez al cabo de dos calendarios, puso estos categóricos conceptos en labios de un libertino: "El romanticismo de Hugo y Dumas causa risa; porque hoy vivimos como Pirrón ${ }^{39}$, que era un ser que especulaba con el cinismo como los otros con las grandes pasiones" ${ }^{\prime 0}$. Si bien las frases son adecuadas a la filosofía del personaje ficticio que las expresa, revelan en alguna medida las ideas de su creador. En realidad, es comprensible que, superados los años de la adolescencia y primera juventud, sus gustos e intereses cambiaran no solo por el natural paso del tiempo y consiguiente maduración psicosomática, sino por la permanente influencia de corrientes y estilos acompañados de sensibilidades distintas y hasta opuestas a las de los grandes románticos franceses. Así, a pesar de la ironía, los conceptos siguientes, escritos en 1860, corroboran su alejamiento espiritual de los moldes galos y su aproximación a los españoles:

Cúponos en suerte o en desgracia nacer en este siglo de carbón de piedra tan dado al romanticismo de Víctor Hugo, como poco amante del que se estilaba en los días de Calderón. Y a fe, que si ahora cuando se escribe una relación de amores entran en ella puñal y veneno, en los benditos tiempos de la capa y la espada todo era serenatas y tal cual zurra a los alguaciles de la ronda. No embargante, si alguna

39 Pirrón, filósofo escéptico griego de los siglos IV y III a. C.

40 Cf. Los Noticiosos (seud. de Palma et ál.), "La tijerita", en [El] Correo de Lima, 16? dic. 1851, núm. roto, 3, 3; El Cronicastro, ¿Palma?, también elogió a Dumas en una "Crónica teatral", ibíd., 27 dic. 1851, 95, 2, 2-3 y 3, 1-2; Lida, I, pp. 2-3; El Comercio, Lima, 2 nov. 1855, 4877, 2, 5 y 3, 1; y "La venganza de un ánjel [sic]", en Biblioteca Nacional del Perú, ms. D-2394, respec. Palma repitió sus críticas a Hugo y Dumas en "Poetas peruanos. Don Carlos Augusto Salaverry (poeta dramático)”, p. 299. 
vez relucía la fina hoja de Toledo era en apartado campo y caballerosa lid y los desafíos terminaban tiñéndose en sangre el gavilán del hierro. Parece que el romanticismo de nuestros abuelos no había descubierto que las más guapas armas para un combate son dos botellas de lo tinto, y el mejor palenque una buena mesa provista de un suculento almuerzo a la parisiense ${ }^{41}$,

lo que explicaría la inexistencia de censuras contemporáneas hacia estos últimos. Todo ello no impide aseverar que Dumas fue un dramaturgo respetado, y posiblemente imitado, por Palma en sus primeros años de escritor, tanto que alguien conocedor de sus afectos literarios lo halló émulo del polígrafo francés ${ }^{42}$. Palma debió de conocer a Dumas entre 1864 y $1865^{43}$.

Trayectoria semejante -de la admiración al rechazo- siguieron en el desarrollo espiritual y artístico de Palma otros dos dramaturgos galos: Frédéric Soulié (1800-1847) y Joseph Bouchardy (18101870). Soulié, elogiado por el "bohemio" Juan Sánchez Silva nada menos que en el prólogo al drama Rodil de Palma (1851), cuando ambos valoraban semejantemente a autores y obras, fue mencionado más adelante, al lado de Dumas, como creador de "dramones" 44 .Bouchardy, cuya popular obra "Paris, le bohémien" ("El Gitano o la terrible venganza") tradujo Palma al español para un beneficio del actor Mateo O’Loghlin (1854), traducción elogiada por la prensa, más tarde mereció su censura por escribir dramas patibularios, intrascendentes y modelo de mal gusto ${ }^{45}$.

41 Cf. "Un bofetón a tiempo", p. 117.

42 Cf. El Comercio, Lima, 14 ene. 1852, 3750, 3, 5.

43 TPC, p. 1418.

44 Cf. El Comercio, Lima, 2 nov. 1855, 4877, 2, 5 y 3, 1.

45 Cf. ibíd., 20 dic. 1858, 5881, 3, 2-3; Holguín Callo, Tiempos de infancia y bohemia ... cit., pp. 345-49; y Ugarte Chamorro, Ricardo Palma, autor teatral, pp. 148-53. Palma volvió a mencionar "esos dramones de efecto, a lo Bouchardy" en "La bohemia..." cit., p. 43. 
Palma también tradujo en verso castellano, en compañía del "bohemio" José Toribio Mansilla, el libreto francés de "La Favorite" ("La Favorita") (1852), ópera de Donizetti" "Sullivan", comedia de Anne-Honoré-Joseph Duveyrier de Mélesville (1787-1865); Próspero Mérimée (1803-1870), autor de la comedia "La Carrosse du Saint-Sacrement", con la Perricholi como protagonista, y el dramaturgo Émile Augier (1820-1889), también figuraban entre sus conocidos ${ }^{47}$.

En el campo de la narración, Palma sin duda leyó a Chateaubriand $(1768-1848)^{48}$, pero fueron las novelas históricas de Dumas como las de Scott y Fernández y González ${ }^{49}$ - lo que le hizo uno de sus autores favoritos en la adolescencia y juventud: "Los tres mosqueteros", "Veinte años después", etc. La popularidad de aquella entre los "bohemios" era tan grande que a uno de ellos, Manuel Trinidad Pérez, por su vigor físico, Cisneros y Salaverry lo apodaron Porthos $^{50}$. Eugenio Sue (1804-1857), por su muy popular El judio errante y Los misterios de París, y Hugo, por Nuestra Señora de París con su atormentado personaje el sacerdote Claudio Frollo, y por Los miserables, fueron algunas de las muchas novelas y novelitas francesas que impresionaron su fantasía durante la lectora adolescencia que le tocó vivir ${ }^{51}$.

46 Cf. Holguín Callo, op. cit., pp. 337-44; y Ugarte Chamorro, op. cit., pp. 147-48.

47 Cf. Holguín Callo, op. cit., p. 346 nota; y Palma, TPC, pp. 621 y 1515, respec.

48 "Flor de los Cielos", leyenda en verso de Palma (1852), como otras obras del romanticismo hispanoamericano, posiblemente recibió influencia de Atala (cf. Carilla, El romanticismoen la América hispánica, I, p. 73; y Winn, "Más sobre las fuentes..." cit., p. 806).

49 Palma, TPC, p. 1475, y "Manuel Fernández y González”.

50 Palma, "La bohemia..." cit., p. 47.

51 Palma, TPC, p. 1131; y Los Duendes (seud. de Palma), "Revista de teatro. Opera. El criminal por honor. La cruz de Malta”, en El Intérprete del Pueblo, Lima, 5 jun. 1852, 106, 3, 2-3. El judio errante salió en el folletín de El Comercio y poco después se convirtió en libro por entregas; eds. francesas y chilenas de Dumas llegaron tempranamente (cf. El Comercio, Lima, 29 nov. 1845, 4, 3; y 21 ene. 1848, 2573, 1, 4). Véase también Winn, op.cit., p. 805. 
Balzac (1799-1850) fue un autor que Palma no solo leyó sino admiró: "gran novelista francés" lo llama, atribuyéndole, muy a su estilo, el haber puesto sobre el tapete, entre los cónyuges, la separación de lecho y aun de dormitorio... ${ }^{52}$.

No debe preterirse su contacto con algunos clásicos franceses, como Molière (1622-1673)53, Racine (1639-1699), Corneille (1606-1684) ${ }^{54}$, Malherbe (1555-1628), Fénelon (165 1-1715), cuyo Les aventures de Télémaque, como se ha visto, le sirvió para ejercitarse en el idioma, pero sobre todo el influyente retórico y poeta Boileau (1636-1711), con quien más de una vez se identificó por completo: "iAh, padre y maestro Boileau! ¿Por qué cuando Galdós escribía esa escena [de su drama "Electra"], tu espíritu no murmuró a su oído aquel tu precepto inmortal: ¿Rien n'est beau que la vraie?" 55 ; como se verá, ya lo había citado en su propio idioma y hasta conocía de memoria sus dictados.

No era un secreto su admiración por Voltaire (1694-1778). De ella y de su volterianismo se han ocupado destacados estudiosos (Arciniega ${ }^{56}$, Miró ${ }^{57}$, Miró Quesada S. ${ }^{58}$ y Núñez ${ }^{59}$, entre otros). Igualmente, se han detectado las ocasiones en que lo mencionó

52 TPC, pp. 1052 y 1 174. Winn afirma que, por lo menos, Palma conoció sus obras Les resources del Quinola y Filosofía del matrimonio (Winn, op. cit., p. 805; y Palma, $T P C$, p. 1726). José Durand insinúa que Balzac pudo influir en Palma a través de sus Cuentos droláticos (apud Núñez, "Juan Vicente Camacho en el Perú”, p. lv).

53 “Aquellos dos versos: '....aquí hay una cruz / no la vayan a pisar', con que finaliza el tercer acto, son plumada de maestro. Molière no las tiene superiores” (Palma, "Preámbulo biográfico y noticiero", p. vii; y "Poetas peruanos..." cit., p. 301); véase también El Comercio, Lima, 31 dic. 1846, 2261, 4, 1; y El Tío Pepinitos (seud. de Palma) et ál., "Revista teatral", ibíd., 2 feb. 1858, 557 1, 4, 4-5.

54 Cita de su tragedia "Horace" en TPC, p. 1155.

55 Carta a Rafael Altamira de Lima y (2 may. 1900), en Epistolario, I, p. 479.

56 “El 'volterianismo' de Ricardo Palma”.

57 "El volterianismo de don Ricardo".

58 "Palma y Voltaire".

59 "Voltaire en Ricardo Palma y en González Prada". 
y algunas de las obras que leyó ${ }^{60}$. En 1878, al conmemorarse en Lima el centenario del gran escéptico, Palma declaró que no era volteriano y hasta dijo discrepar de algunos de sus postulados, dejando incólume su admiración al escritor ${ }^{61}$. Sin duda, Palma asumió ciertas actitudes volterianas que amenguó su genio festivo, pero no en todos los frentes ni con la misma agudeza. Según Riva-Agüero, para ser volteriano "le faltaban la variedad de tonos, el ardiente proselitismo y la malignidad emponzoñada del Patriarca de Ferney"62.

Más allá de la literatura, Palma frecuentó a autores como el Duque de Saint-Simon (1675-1755) (3) $^{6}$, sin duda, bebió en algunas obras de los "enciclopedistas y filósofos franceses", como Diderot (1713-1784), Rousseau (1712-1778), el abate Prévost (1697-1763), Volney (1757-1820), D'Alembert (1717-1783) y Crébillon (1674-1762) ${ }^{64}$. Igualmente, consultó libros de viaje como los de Lafond, Tristán, Radiguet, etc. ${ }^{65}$.

Frente al parnasianismo francés, Palma parece haberlo aceptado si se da crédito a la siguiente frase escrita para elogiar al poeta español Salvador Rueda:

No es, por la forma, un poeta español, sino un parnasiano francés (y eso que ni lo habla ni lo traduce) de los que hacen filigrana con el oro de la palabra. En cuestión de escuela

60 Winn refiere las veces y motivos por los que es citado en las tradiciones, así como las obras que Palma menciona: Candide, La Pucelled'Orleans, La Comisandra, La Henriade, Zaire, etc. ("Más sobre las fuentes..." cit., p. 804).

61 Cf. Miró Quesada S., "Palma y Voltaire”, p. 60.

62 Apud ibíd., p. 58.

63 Cuyas Memorias leyó y quizá empleó en su tradición "El chocolate de los jesuitas" (TPC, p. 633); y Winn, op. cit., pp. 804 y 806.

$64 T P C$, p. 1279, e índice onomástico. Véase también Winn, op. cit., pp. 804.

65 Véase TPC, índice onomástico. Por otra parte, son numerosos los franceses mencionados de paso en las tradiciones, como los naturalistas Frouessart y Boulenger, el inventor Montgolfier, etc. 
literaria, no entro ni salgo. Mi estética es la de Boileau: Tous les genres sont bons hors le genre ennuyeux [Todos los géneros son buenos menos el género aburrido] ${ }^{66}$.

Lo cierto es que, salvo excepciones, Palma no tenía una buena opinión de las modernas escuelas literarias, como deja ver en esta sincera comunicación personal: "Los parnasianos, los modernistas, los decadentes, los simbolistas y demás sectarios de escuelas malsanas, tienen mucho de neuróticos. Son escuelas que han nacido enfermas, como las califica Núñez de Arce"67. Es más, culpaba a los poetas franceses de lo que estaba ocurriendo en los países hispanoamericanos:

En las repúblicas de Centro-América, como en las de Colombia, en Cuba, en el Perú, en México, por todas partes, en fin, ha cundido esa filoxera de la poesía extravagante puesta a la moda por media docena de poetas franceses. La lengua castellana, más rica, más musical, más abundante de onomatopeyas que la francesa, se ha prestado prodigiosamente a esa poesía palabrera e insustancial que reniega de las creencias más consoladoras para el espíritu y

66 “Recuerdos de España...” cit., pp. 217-18. Núñez asegura que la afición de Palma por Baudelaire "se encuentra en algún epígrafe” y que "había leído detenidamente a Théodore de Banville..." (Las letras de Francia y el Perú, pp. 235-236).

67 Carta a Román Pacheco, de Lima y 2 oct. 1894, en Epistolario, I, p. 359. Por los mismos días, reiteró sus condenas al modernismo, esa vez públicamente: "En el autor de este libro [el poeta ecuatoriano Leónidas Pallares Arteta] hay más tendencia al espiritualismo romántico de Bécquer que a la fosforescencia pesimista de Verlaine y Richepin... Esa literatura de bibelots, de japonerías, literatura de neuróticos, literatura fin de siècle, está llamada a tener la vida [de] los infantes que nacen enfermos. De los sietemesinos no se hacen los atletas, ni en el mundo físico ni en el mundo de las ideas. Quiera mi joven amigo permanecer siempre leal a la buena escuela literaria, ...y no se deje arrastrar por la corriente de la moda a las filas de los alucinados sectarios del modernismo" ("Pocas palabras", pp. iii-iv). En 1892 ya había mencionado al controvertido poeta Richepin ("Recuerdos de España..." cit., p. 129). 
de los ideales más levantados para la inteligencia. Como el realismo de Zola, con todas sus asquerosidades de lupanar y de hospital, pasará de moda ${ }^{68}$.

La cita, además de advertir las preferencias de Palma por la lengua castellana, sirve para confirmar sus condenas a la moderna novela francesa, ya manifestadas en el discurso de orden que en 1887 había pronunciado en la instalación de la Academia Correspondiente de la Real Española: “...literatura pornográfica que, hasta manufacturada, digámoslo así, nos imponen ogaño los novelistas franceses..."69. Sus condenas a la novela realista de autores como Zola se iban a repetir: “...detalles pornográficos tan subidos de color como los de Zola en Germinal y en Terré"70.

A manera de comentario y balance provisional, se puede asegurar que Palma fue un gran admirador y hasta un devoto de la literatura francesa clásica y romántica, pero un severo crítico de la inspirada por el realismo, el modernismo, el parnasianismo, el simbolismo, etc. La evolución de los gustos y moldes literarios no lo acompañó siempre, no podía hacerlo, durante la larga existencia que le tocó vivir, menos aun cuando en las últimas décadas del siglo XIX y primeras del XX, las de su edad madura y senectud, contempló el surgimiento de escuelas y doctrinas literarias reñidas con las que entrañablemente había hecho suyas desde la más temprana edad.

68 Carta a Román Pacheco, de Lima y 2 oct. 1894, en Epistolario, I, pp. 359-60. Ya en 1881 había aludido al realismo de Zola (cf. carta a Nicolás de Piérola, de Lima y 3 set. 1881, en Cartas inéditas, p. 57); y en 1888, en tanto "creador de la novela naturalista", lo hizo responsable de herir "casi de muerte la, bajo mil razones, trascendental e ingeniosa novela histórica..." ("Manuel Fernández y González").

69 "Discurso de orden en la inauguración de la Academia Correspondiente de la Real Española”, p. 169. Los resaltes son originales.

70 "Prólogo" (1899), p. vii. 


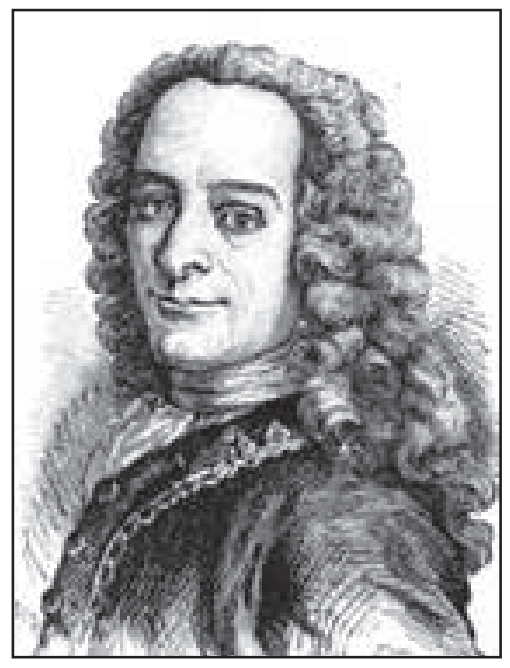

Voltaire

\section{Bibliografía}

ARCINIEGA, Rosa. "El 'volterianismo' de Ricardo Palma", en Cuadernos (del Congreso por la Libertad de la Cultura) (París, nov.-dic. 1958), 33, pp. 25-28; y, como "Volterianismo", en Flores, Ángel; et ál.Orígenes del cuento hispanoamericano. Ricardo Palma y sus Tradiciones. Estudios, textos y análisis (México D. F., Premia Editora de Libros S. A., 1979), pp.81-85.

CARILlA, Emilio. El romanticismo en la América hispánica. Segunda edición revisada y ampliada. Madrid, Editorial Gredos, 1967. 2 vols.

CEJADOR Y FRAUCA, Julio. Historia de la lengua y literatura castellana. (Comprendidos los autores hispano-americanos). (Desde los orígenes hasta Carlos V). Edición facsímil. Madrid, Editorial Gredos, 1972. 14 vols.

COMPTON, Merlin D. (comp.). La trayectoria de las primeras tradiciones de Ricardo Palma. Providence, R. I.; Textos del V Centenario, 1989. 
GONZÁlEZ, Nicolás Augusto. Víctor Hugo. A mi maestro y amigo Ricardo Palma, en El Ateneo de Lima (Lima, 1887), 4: 37, pp. 83 y 102-10.

HOlguín CAllo, Oswaldo. Palma, cónsul en el Pará, en Boletín de la Academia Peruana de la Lengua (Lima, 1983), nueva época, 18, pp. 73-120.

- Tiempos de infancia y bohemia. Ricardo Palma (1833-1860). Lima, Pontificia Universidad Católica del Perú, 1994.

MIRÓ, César. El volterianismo de don Ricardo, en El Comercio (Lima, 9 oct. 1969), p. 2.

MIRÓ QUESADA S., Aurelio. Palma y Voltaire, en su Palabras sobre Palma (Lima,Talls. Gráfs. P. L. Villanueva, 1969), pp. 57-61.

MOREYRA Y PAZ SOLDÁN, Manuel. Pedro Ignacio Noboa y Benavides, economista, político, literato, diplomático, en Revista Histórica (Lima, 1949), 18, pp. 247-92.

NÚÑEZ, Estuardo. La conmoción romántica: Víctor Hugo, en su Las letras de Francia y el Perú cit. infra, pp. 125-35.

__ La efusión sentimental: Lamartine y Musset, ibíd., pp. 137-45.

_ “uan Vicente Camacho en el Perú", en Camacho, Juan Vicente. Tradiciones y relatos. Estudio biográfico-crítico y recopilación... (Caracas, Ministerio de Educación, Dirección de Cultura y Bellas Artes, 1962), pp. ix-lxxx.

L Las letras de Francia y el Perú. Apuntaciones de literatura comparada. Lima, Universidad Nacional Mayor de San Marcos, 1997. 21-24.

Víctor Hugo en el Perú, en Mar del Sur (Lima, mar.-abr. 1952), 20, pp.

Voltaire en Ricardo Palma y en González Prada, en su Las letras de Francia y el Perú cit. supra, pp. 50-51.

PALMA, Ricardo. Armonías. Libro de un desterrado. París y México, Lib. de la Vda. de Ch. Bouret, 1912. 
-Un bofetón a tiempo, en Compton, La trayectoria de las primeras tradiciones de Ricardo Palma cit. supra, pp. 117-20.

L La bohemia de mi tiempo. 1848 a 1860. Confidencias, en su Recuerdos de España, precedidos de La bohemia de mi tiempo cit. infra, pp. 1-72.

Cartas inéditas de don Ricardo Palma. Introducción y notas de: Rubén Vargas Ugarte, S. J. Lima, Carlos Milla Batres, 1964.

— La conciencia, en La Revista de Lima (Lima, 15 abr. 1860), 1: 14, pp. 672-73. Traducción de Víctor Hugo.

Consolación. Confidencias, en Compton, La trayectoria de las primeras tradiciones de Ricardo Palma cit. supra, pp.19-23.

Discurso de orden en la inauguración de la Academia Correspondiente de la Real Española, en su Ropa Vieja. Última serie de tradiciones (Lima; Imp. y Lib. del Universo, de Carlos Prince; 1889), pp. 167-74.

Dos mil setecientas voces que hacen falta en el Diccionario. Papeletas lexicográficas. Lima, Imprenta La Industria, 1903.

- iiEnrique Alvarado!!, en Tauro, Alberto (comp.). Poesías olvidadas de Ricardo Palma(Lima, 1963; separata de Sphinx), pp. 197-99.

—_Epistolario. Lima, Editorial Cultura Antártica, 1949. 2 vols.

_ Filigranas... Aguinaldo a mis amigos. Lima, $1^{\circ}$ de enero de 1892. Lima, Imp. de Benito Gil, 1892.

Lida. Romance histórico escrito para folletín del Mensagero [sic]. Lima, Imp. del Mensagero (sic), 1853. Suscrito: Manuel Ricardo Palma.

—_Manuel Fernándezy González, en Prince, Carlos (ed.). Boletín Bibliográfico (Lima, $1^{\circ}$ abr. 1888), 1: 4, p. 35. Suscrito: R. P.

— Pocas palabras, en Pallares Arteta, Leónidas. Rimas (Lima; Lib., Imp. y Encuadernación Gil; 1894), pp. i-iv.

_ Poesías completas. Barcelona, Casa Editorial Maucci, 1911. 
_ Poesías de Ricardo Palma. Juvenilia. Armonías. Cantarcillos. Pasionarias. Traducciones. Verbos y gerundios. Nieblas. Lima, Imp. de Torres Aguirre, 1887.

— Poetas peruanos. Don Carlos Augusto Salaverry (poeta dramático), en La Revista de Lima (Lima, 15 abr. 1861), 3: 38, pp. 298-303.

— Preámbulo biográfico y noticiero, en Segura, Manuel Ascensio. Artículos, poesías y comedias (Lima; Carlos Prince, Impresor y Librero-Editor; 1885), pp. v-viii.

_ Prólogo, en Flor de academias y Diente del Parnaso. Edición oficial (Lima, Oficina Tipográfica de El Tiempo, 1899), pp. iii-xx.

— Prólogo, en Segura, Manuel Ascensio.Teatro. Precedido de un prólogo (Lima, Imp. de La Juventud por Guillermo Guerrero, 1858), pp. iii-vii. Suscrito: Manuel Ricardo Palma.

—_Recuerdos de España. 1892 a 1893, en su Recuerdos de España, precedidos de La bohemia de mi tiempo cit. infra, pp. 73-222.

—_Recuerdos de España, precedidos de La bohemia de mi tiempo. Lima, Imp. La Industria, 1899.

— Tradiciones peruanas completas. Edición y prólogo de Edith Palma, nieta del autor, con siete extensos apéndices y una selección de cartas del autor. Madrid, Aguilar, 1964. $5^{\mathrm{a}}$ ed.

Traducción de Víctor Hugo, en La Revista de Lima (Lima, $1^{\circ}$ set. 1860), 2: 23, p. 214 .

_Una visita a la tumba de Alfredo de Musset, en La Revista de Buenos Aires (Buenos Aires, nov. 1864, 5: 19), pp. 483-87, sec. "Literatura".

RIVA-AGÜERO, José de la. D. Ricardo Palma, en Mercurio Peruano (Lima, ene. 1920), 19, pp. 3-19.

_ Elogio de don Ricardo Palma, en Sociedad Amigos de Palma, Ricardo Palma 1833[-]1933 (Lima, Cía. de Impresiones y Publicidad, 1934), pp. 15-42. 
SILVA-SANTISTEBAN, Ricardo (comp.). Victor Hugo en el Perú. Selección y presentación de... Lima, Embajada de Francia y Pontificia Universidad Católica del Perú, 2003.

TAUZIN CASTELLANOS, Isabelle. Los románticos peruanos y París, en París y el mundo ibérico e iberoamericano (París,Université Paris X-Nanterre, Centre de Recherches Ibériques et Ibéroaméricaines, 1998), pp. 231-42.

UGARTE CHAMORRO, Guillermo. Ricardo Palma, autor teatral. Lima, 1976. Separata de San Marcos.

WINN, Conchita Hassell. Más sobre las fuentes y documentos de información de que se sirvió Ricardo Palma: sus lecturas en lenguas extranjeras. Revista Hispánica Moderna (Nueva York, jul.-oct. 1968), 34: 3-4, pp. 799-809. 